ISSN: 1858-4837;E-ISSN: 2598-019X

Volume 16, Nomor 1 (2021),

https://jurnal.uns.ac.id/region

DOI: 10.20961/region.v16i1.40088

\title{
Analisa faktor yang mempengaruhi akses air minum dan pengelolaan tinja berbasis masyarakat di Provinsi Maluku
}

\author{
Analysis of factors affecting community-based water supply and management \\ of fecal waste in Maluku Province
}

\author{
Y Adicita1 ${ }^{1}$ I W K Suryawan², A J Pesurnay ${ }^{1}$ \\ ${ }^{1}$ Program Studi Teknik Lingkungan, Fakultas Teknik, Universitas Universal \\ ${ }^{2}$ Program Studi Teknik Lingkungan, Fakultas Perencanaan Infrastruktur, Universitas \\ Pertamina
}

Corresponding author's email: i.suryawan@universitaspertamina.ac.id

\begin{abstract}
Abstrak. Provinsi Maluku merupakan provinsi kepulauan yang terdiri atas 1.412 pulau. Pulau tersebut harus dilayani dengan akses air minum dan pengolahan air limbah dari tinja. Penelitian ini dilakukan untuk melihat kondisi eksisting dan menganalisa faktor yang signifikan mempengaruhi akses air minum dan pengelolaan tinja. Faktor yang digunakan dalam analisa yaitu pendidikan, kepadatan penduduk, jenis rumah, kepemilikan rumah, dan pengolahan air. Kabupaten Kepulauan Aru memiliki persentase rumah permanen dan kepemilikan rumah yang cukup rendah dengan nilai $49,12 \%$ dan $41,8 \%$. Penggunaan air kemasan bermerek dipengaruhi oleh pendidikan, kepadatan penduduk, dan pengolahan air. Penggunaan air sumur bor/pompa dan sumur tidak terlindung dipengaruhi oleh tingkat pendidikan. Pengelolaan tinja lebih dipengaruhi oleh jenis rumah dan kepemilikan rumah.
\end{abstract}

Kata Kunci: Akses Air Minum; Faktor Pengaruh; Pengelolaan Tinja

\begin{abstract}
Maluku Province is an archipelago province consisting of 1,412 islands. The island must be served by access to drinking water and fecal waste management. This research was conducted to look at existing conditions and analyze factors that significantly affect access to drinking water and fecal waste management. The factors used in the analysis are education, population density, house type, homeownership, and water treatment. Aru Islands Regency has a relatively low percentage of permanent housing and homeownership with values of $49.12 \%$ and $41.8 \%$. The use of branded bottled water are affected by education, population density, and water
\end{abstract}

Received : February 19, 2020; Accepted: July 14, 2020; Available online: January 30, 2021

Copy right $\odot$ 2021, REGION: Jurnal Pembangunan Wilay ah dan Perencanaan Partisipatif 
treatment. The use of water from boreholes/pumps and unprotected wells is affected by the education level. Whereas fecal management is more affected by house type and house ownership.

Keywords: Access to Drinking Water; Factors Affecting; Fecal Waste Management

\section{Pendahuluan}

Provinsi Maluku terbentuk dari gugus kepulauan yang terbesar di Indonesia yang terletak antara $3^{\circ}$ Lintang Utara - $3^{\circ}$ Lintang Selatan dan $124^{\circ}$ - $136^{\circ}$ Bujur Timur [1]. Provinsi Maluku terdiri dari sembilan kabupaten dan dua kota yang berbatasan langsung dengan laut. Beberapa pulau tersebut merupakan pemukiman yang harus dilayani oleh pemerintah. Berdasarkan Program 100-0-100 yang masuk dalam Rencana Pembangunan Jangka Menengah Nasional (RPJMN) 3 tahun 2014-2019 [2]. Program 100-0-100 menuntut ketersediaan 100 persen air minum, 0 persen kawasan kumuh, dan 100 persen fasilitas sanitasi serta drainase di seluruh wilayah Indonesia. Menurut Dahlan, strategi pemerintah dalam mewujudkan program tersebut di Provinsi Maluku khususnya di Kota Ambon adalah pembangunan dan perbaikan drainase lingkungan, penyediaan air bersih, pengelolaan persampahan, prasarana pengelolaan air limbah, dan penguatan kapasitas masyarakat [3].

Akses air minum yang layak mencakup kuantitas dan kualitas yang baik dan terjaga. Secara kuantitas air minum yang digunakan oleh masyarakat harus mengalir terus menerus serta secara kualitas harus memenuhi baku mutu air minum [4]. Akses air minum merupakan salah satu hal dasar yang harus disediakan kepada masyarakat. Pengembangan dan pengelolaan sumber daya air di Indonesia masih berorientasi pada penyediaan [5]. Ketersediaan air minum harus memperhatikan risiko kekeringan terutama disebabkan oleh peningkatan populasi dan pertumbuhan yang cepat karena pembangunan yang mengarah pada kebutuhan air bersih yang sangat tinggi, sementara tingkat penyediaan air bersih tidak banyak meningkat tetapi menjadi lebih tidak pasti [6]. Ketidakpastian jumlah air yang tersedia juga dipengaruhi oleh pencemaran sumber daya air yang diakibatkan oleh perilaku buang air sembarangan. Air limbah yang dibuang ke lingkungan tanpa adanya pengolahan berdampak pada penurunan kualitas lingkungan [7, 8]. Hasil penelitian di daerah Seram Bagian Timur menyebutkan saluran pembuangan air buangan masih belum memenuhi syarat karena masyarakat belum memiliki kesadaran untuk memiliki saluran pembuangan air buangan sendiri yang baik [9]. Saluran air buangan yang layak seharusnya terpisah dengan drainase agar berfungsi sebagaimana mestinya agar tidak te rjadi peluapan air dan terjadinya genangan [10].

Pengelolaan air minum dan perilaku pengelolaan tinja merupakan aspek teknis yang berkaitan dengan kondisi sosial masyarakat. Tujuan dari penelitian ini adalah untuk mengetahui kondisi eksisting dan faktor yang mempengaruhi pengelolaan air minum dan buangan tinja. Faktor yang dianalisa yaitu pendidikan, kepadatan penduduk, jenis rumah, kepemilikan rumah, dan pengolahan air. 


\section{Metode}

\subsection{Ruang lingkup}

Penelitian ini dibatasi berdasarkan faktor-faktor yang berkaitan dengan masyarakat yaitu pendidikan, kepadatan penduduk, jenis rumah, kepemilikan rumah, serta pengolahan air. Faktor-faktor tersebut merupakan variabel dependent dalam penelitian ini. Variabel independent dalam pengelolaan air minum yaitu penggunaan air kemasan bermerek, air isi ulang, ledeng meteran/eceran, sumur bor/pompa, sumur terlindung, sumur tidak terlindung, mata air terlindung, mata air tidak terlindung, air permukaan, dan air hujan. Dalam pengelolaan tinja variabel yaitu tangki septik, SPAL (sistem penyaluran air limbah), dan pengelolaan yang tidak layak seperti pembuangan langsung ke kolam/sawah/sungai/danau/ laut/lubang tanah/pantai/tanah lapang/kebun/dan lainnya.

\subsection{Pengambilan data}

Data yang digunakan adalah data sekunder dari Badan Pusat Statistik yaitu Statistik Kesejahteraan Maluku Tahun 2017 [11]. Selain data tersebut digunakan data berdasarkan Dinas Kesehatan Provinsi Maluku yaitu profil Kesehatan Provinsi Maluku Tahun 2014 [12]. Penggunaan data tersebut didasarkan pada tahun terakhir data tersebut dikeluarkan oleh pemerintah.

\subsection{Analisa data}

Dalam penelitian ini faktor dikelompokkan berdasarkan 4 tingkat yaitu partisipasi sangat rendah, rendah, sedang, dan tinggi. Perhitungan yang digunakan dalam pengelompokan data yaitu berdasarkan penentuan interval kelas dihitung berdasarkan persamaan 1 . Analisa data lebih lanjut dilakukan dengan program SPSS. One Way Anova dilakukan untuk menguji faktor pendidikan, kepadatan penduduk, jenis rumah, kepemilikan rumah, dan pengolahan air terhadap pengelolaan air minum dan pengelolaan tinja.

$\mathrm{I}=\mathrm{R} / \mathrm{K}$

Dimana :

I = Interval kelas

$\mathrm{R}=$ Range

$\mathrm{K}=$ Banyak kelas yang akan dibuat

\section{Hasil dan pembahasan}

\subsection{Kondisi eksisting penduduk Provinsi Maluku}

Pendidikan merupakan salah satu faktor yang dapat menentukan pola pikir se seorang dalam penerapan penggunaan air minum dan pembuangan tinja. Dalam penelitian ini dilakukan pengelompokan data berdasarkan pendidikan terendah yaitu SMA/SMK ke atas. Berdasarkan data BPS Maluku [11], persentase penduduk yang lulus SMA/SMK ke atas di Kabupaten Maluku Barat Daya, Buru Selatan, dan Kepulauan Aru memiliki persentase yang sangat rendah yaitu 27,51; 31,58; dan 33,11\% (Gambar 1). Persentase penduduk lulusan SMA/SMK ke atas tertinggi yaitu Kota Ambon dengan persentase $64,77 \%$ dan Kota Tual masuk ke dalam kelompok menegah (50,71\%). 


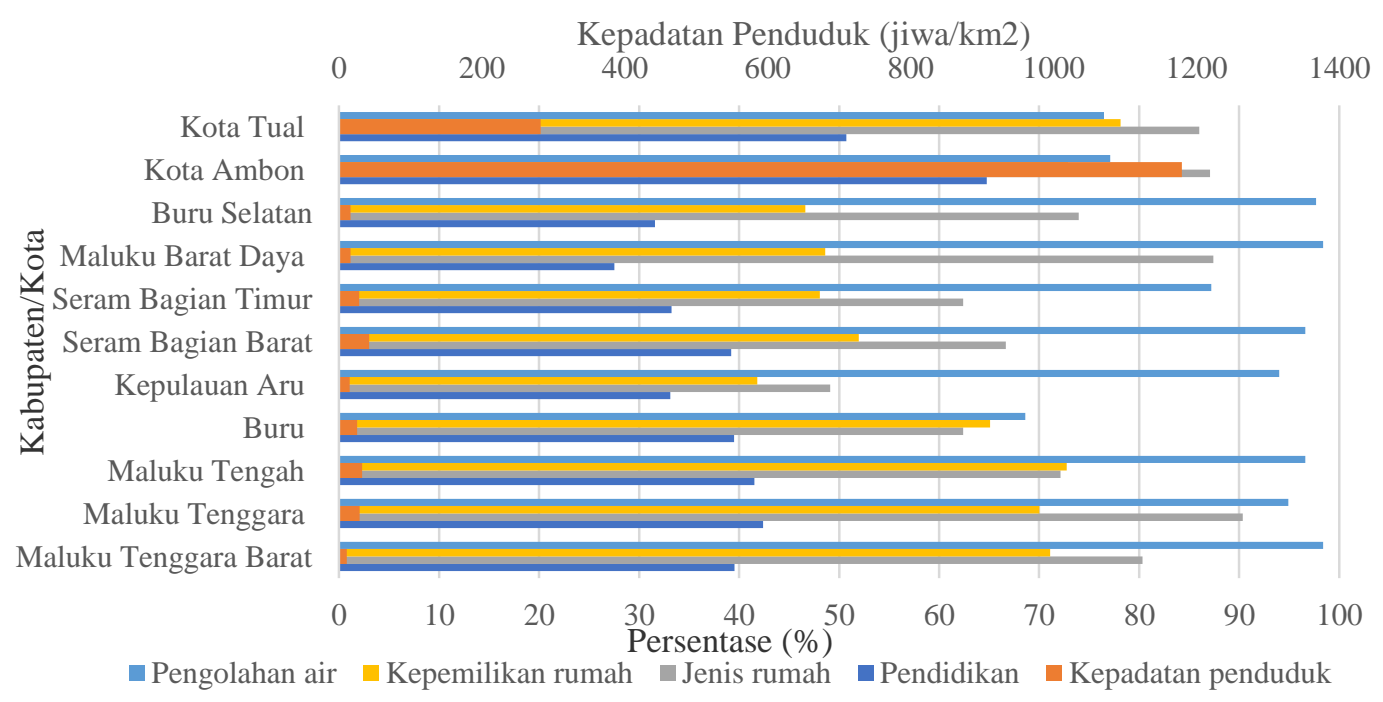

Gambar 1. Kondisi eksisting penduduk di Provinsi Maluku [11].

Kepadatan penduduk menentukan jenis teknologi yang dapat diaplikasikan karena kebutuhan lahan di suatu wilayah. Kota Ambon merupakan salah satu daerah dengan kepadatan tinggi dengan $1.180 \mathrm{jiwa} / \mathrm{km}^{2}$ (Gambar 1 ). Kota Tual memiliki kepadatan yang rendah dengan kepadatan $282 \mathrm{jiwa} / \mathrm{km}^{2}$, sedangkan kepadatan pada wilayah lain masuk ke dalam kepadatan yang sangat rendah yaitu $11-42 \mathrm{jiwa} / \mathrm{km}^{2}$.

Tingkat kepadatan penduduk suatu daerah diakibatkan oleh urbanisasi tidak terencana yang dapat meningkatkan adanya permukiman yang tidak layak huni lebih cepat [13]. Pemukiman tidak layak huni sangat berkaitan dengan perilaku penduduk dalam pengelolaan air minum dan tinja.

Jenis rumah di Provinsi Maluku dalam penelitian ini dibedakan menjadi jenis rumah permanen dan non permanen. Kabupaten Kepulauan Aru memiliki persentase penggunaan rumah permanen yang sangat rendah dengan persentase 49,12\% (Gambar 1). Dapat dilihat pada Gambar 2 kondisi perumahan nonpermanen di Kota Dobo, Kabupaten Aru. Kabupaten Buru, Seram Bagian Barat, dan Seram Bagian Timur berada dalam kategori sedang dengan persentase 62,42; 66,66; dan 62,41\% serta Kabupaten Maluku Tengah dalam kategori tinggi $72,13 \%$.

Struktur perumahan dibangun dengan bahan tidak permanen yang tidak sesuai untuk perumahan dengan kondisi lokasi seperti lantai tanah, dinding, atap, dan lain-lain sering memiliki fasilitas dasar sanitasi dan air minum yang tidak layak akibatnya penurunan kualitas fasilitas kesehatan [14]. Di daerah kumuh, kendala ruang karena sulitnya instalasi toilet rumah tangga dan membangun tangki septik atau pemasangan pipa saluran air limbah yang baik [15]. 

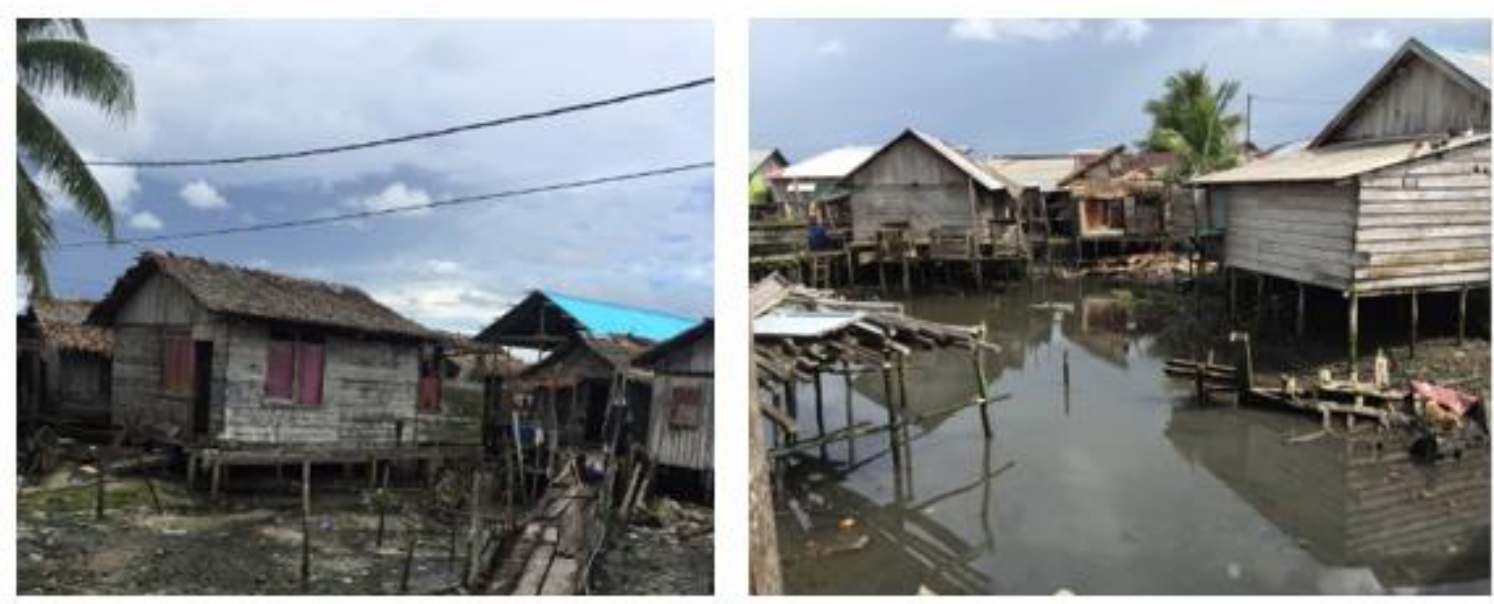

Gambar 2. Perumahan non permanen di Kabupaten Kepulauan Aru.

Kepemilikan rumah merupakan faktor ekonomi yang dapat mempengaruhi tingkat ekonomi produktif suatu rumah tangga [16]. Kepemilikan rumah terendah di Kebupaten Kepulauan Aru (41,8\%) dan kepemilikan rumah tertinggi adalah Kota Tual (78,15\%). Dinamika masyarakat seringkali kurang kohesif daripada di daerah pedesaan, dan hak kepemilikan lahan yang kacau atau tidak aman menyulitkan untuk mengubah perilaku, menetapkan dan mengumpulkan tarif untuk toilet umum, atau membangun struktur permanen yang mahal [17].

Pengolahan air minum penting dilakukan untuk memenuhi persyaratan fisik, kimiawi dan bakteriologis agar memunihi standar kesehatan. Masyarakat Provinsi Maluku melakukan pengolahan air minum dengan cara dimasak sebesar 90,6\%. Proporsi terbesar daerah yang melakukan pengolahan air terdapat di Kabupaten Maluku Barat Daya yaitu sebesar $98,4 \%$ dan terendah di Kabupaten Buru yaitu sebesar 68,5\% [1].

\subsection{Kondisi eksisting akses air minum}

Data BPS menunjukkan bahwa masyarakat Kota Tual dan Kota Ambon memiliki persentase penggunaan air isi ulang yang cukup tinggi yaitu 35,55\% dan 39,56\% (Gambar 3). Masyarakat di daerah pantai menggunakan air isi ulang dan terkadang menggunakan air ledeng dari PDAM sebagai keperluan memasak dan minum [18]. Tingkat pelayanan PDAM menentukan jumlah masyarakat yang menggunakan air PDAM. Provinsi Maluku terdapat tiga PDAM sehat, dua PDAM tidak sehat, dan satu PDAM sakit. PDAM Kabupaten Kepulauan Aru, Maluku Tengah, dan Maluku Tenggara Barat merupakan PDAM yang masuk dalam kategori sehat [19]. Penggunaan air ledeng oleh masyarakat tertinggi adalah di Kabupaten Maluku Tengah (23,2\%) dan didukung oleh PDAM yang sudah dikategorikan PDAM sehat. 


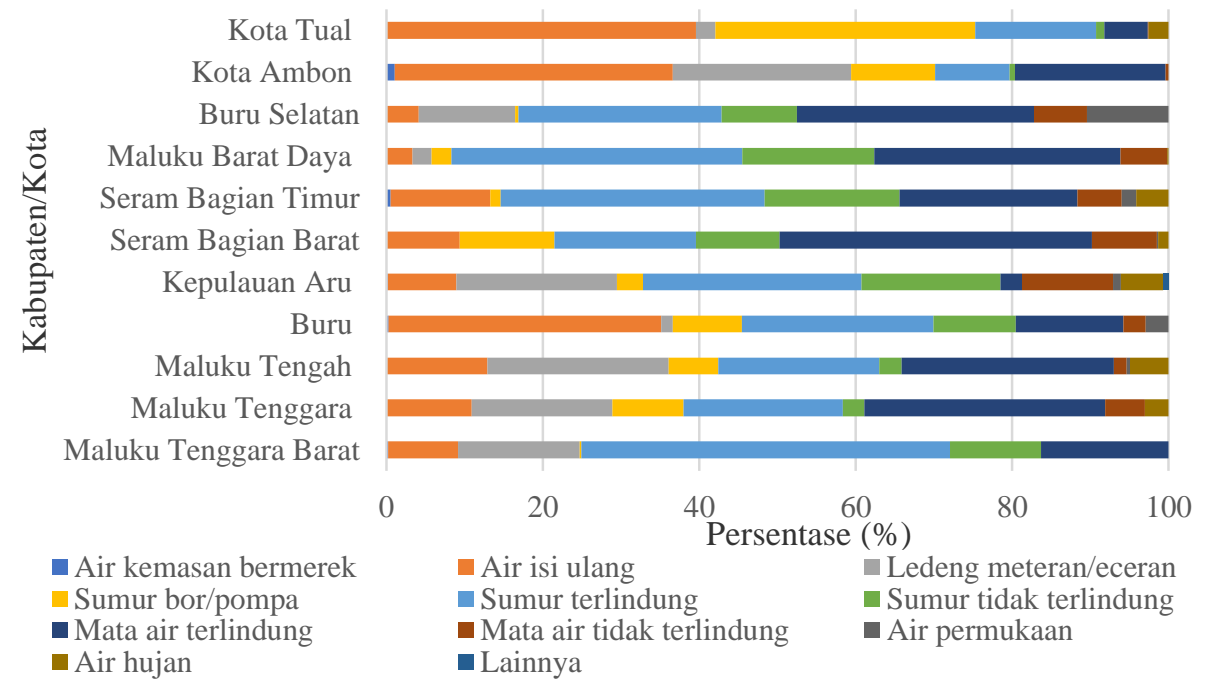

Gambar 3. Kondisi eksisting sumber air yang digunakan penduduk di Provinsi Maluku [11].

Sumur yang digunakan di Provinsi Maluku dibagi menjadi tiga jenis yaitu sumur bor, sumur terlindung, dan sumur tidak terlindung. Penggunaan sumur bor terbesar terdapat di Kota Tual (33,19\%). Penelitian yang telah dilakukan di Kabupaten Maluku Tengah (6,36\%) menyebutkan berdasarkan parameter $E$. coli sumur bor dikategorikan telah memenuhi baku mutu [20]. Sumur bor juga digunakan untuk irigrasi pada pertanian, secara kuantitas menunjukkan kualitas buruk hingga sedang dan se cara kualitas salinitas menunjukkan risiko tinggi hingga risiko rendah [21]. Penggunaan air permukaan terbesar terdapat pada Kabupaten Buru Selatan (10,44\%). Air permukaan yang digunakan sebagai penyedia air minum oleh masyarakat Kabupaten Buru Selatan, salah satunya adalah DAS Wai Tina [22]. Pemanenan air hujan terbanyak dilakukan di daerah Kepulauan Aru $(5,36 \%)$, Maluku Tengah (4,92\%), dan Seram Bagian Timur (4,14\%).

\subsection{Kondisi eksisting pengelolaan tinja}

Rata-rata sudah $82,28 \%$ penduduk Provinsi Maluku sudah menggunakan tangki septik dan hanya $1,51 \%$ penduduk yang menyalurkan air limbah melalui sistem penyaluran air limbah (SPAL) (Gambar 4). Penduduk Kabupaten Maluku Tengah, Buru, Kepulauan Aru, dan Maluku Barat Daya berdasarkan penggunaan tanki septik dibawah rata-rata. Yang mengkhawatirkan adalah 48,5\% penduduk Kabupaten Kepulauan Aru menyalurkan tinja langsung ke lingkungan. Seperti yang penelitian di Sungai Arbes di Kota Ambon menunjukkan tingginya pencemaran akibat limbah domestik yang dibuang langsung ke sungai tersebut dan akan menyebabkan gangguan kesehatan masyarakat sekitar [23]. Selain gangguan kesehatan gangguan lingkungan seperti eutropikasi juga dapat disebabkan oleh pembuangan air limbah sembarangan ke badan air [24]. 


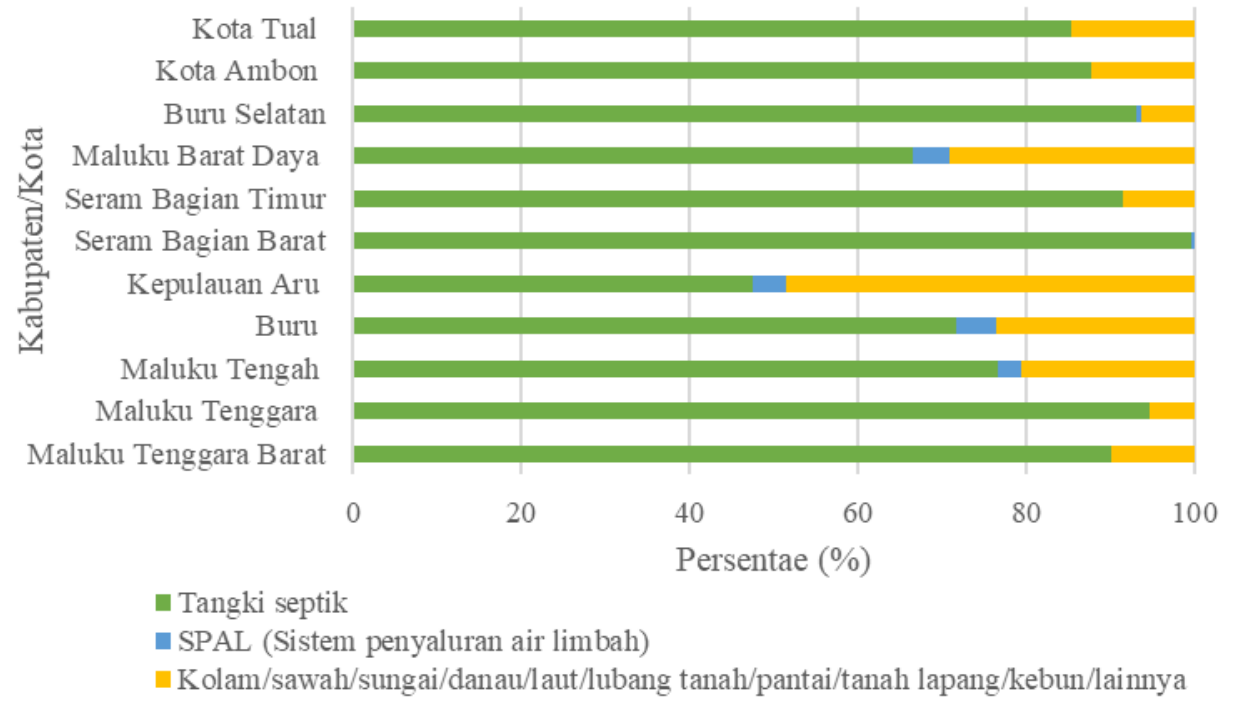

Gambar 4. Kondisi eksisting pengelolaan tinja di Provinsi Maluku [11].

Air permukaan di daerah kepulauan harus tetep dijaga untuk mendukung aktivitas masyarakat pulau terutama masyarakat yang bekerja memanfaatkan sumber daya alam laut. Penurunan kualitas air permukaan akibat pembuangan tinja dapat menyebabkan berkurangnya sumber daya alam. Salah satu contoh adalah Laut Arafura merupakan laut yang berada disekitar Kepulauan Aru, menjadi penting karena berperan menjaga keberlangsungan komoditi mutiara di perairan sekitar [25].

\subsection{Analisa faktor yang berpengaruh dalam akses air minum}

Penggunaan air kemasan bermerek dipengaruhi oleh tiga faktor yaitu pendidikan, kepadatan penduduk, dan pengolahan air. Air kemasan bermerek biasanya dikonsumsi oleh penduduk mayoritas yang memiliki tingkat pendidikan yang tinggi [26]. Penggunaan air kemasan dengan teknologi pengolahan yang efektif sangat penting pada daerah padat penduduk yang sulit air [27]. Penggunaan air isi ulang juga memiliki nilai signifikan yang hampir sama dengan penggunaan air kemasan bermerek (Tabel 1). Tingkat pendidikan masyarakat dalam mengelola air isi ulang sangat penting, terutama dalam teknologi proses pengolahan [28].

Penggunaan air sumur bor/pompa dan sumur tidak terlindung dipengaruhi oleh tingkat pendidikan. Tingkat pendidikan faktor yang berpengaruh dalam pola pikiran seseorang, kepala keluarga berpendidikan rendah cenderung sulit memahami pentingnya sanitasi dasar [29]. Penggunaan sumur bor/pompa di masyarakat yang padat penduduk karena struktur tanah di lokasi yaitu tanah rawa serta kepadatan bangunan dengan demikian tidak memungkinkan untuk menggali sumur [30]. Aset kepemilikan rumah sangat signifikan dalam penggunaan sumur tidak terlindung, mata air tak terlindung, dan air permukaan oleh masyarakat (Tabel 1). Sumber-sumber air tersebut merupakan sumber air yang berlimpah untuk didapatkan oleh masyarakat, sehingga mempermudah masyarakat dalam pengambilan sumber air tersebut. 
Tabel 1. Hasil perhitungan nilai signifikan setiap faktor terhadap sumber air di Provinsi Maluku.

\begin{tabular}{lccccc}
\hline \multicolumn{1}{c}{ Faktor } & Air kemasan & Air isi ulang & $\begin{array}{c}\text { Ledeng } \\
\text { meteran/ } \\
\text { eceran }\end{array}$ & $\begin{array}{c}\text { Sumur bor/ } \\
\text { pompa }\end{array}$ & $\begin{array}{c}\text { Sumur } \\
\text { terlindungi }\end{array}$ \\
\hline $\begin{array}{l}\text { Pendidikan } \\
\text { Kepadatan }\end{array}$ & $\mathbf{0 , 0 1 5}$ & $\mathbf{0 , 0 3 1}$ & 0,544 & $\mathbf{0 , 0 0 1}$ & 0,245 \\
$\begin{array}{l}\text { Penduduk } \\
\text { Jenis Rumah }\end{array}$ & $\mathbf{0 , 0 0 4}$ & $\mathbf{0 , 0 2 2}$ & 0,351 & $\mathbf{0 , 0 0 1}$ & 0,150 \\
Kepemilikan & $\mathbf{0 , 9 3 9}$ & $\mathbf{0 , 9 4 0}$ & $\mathbf{0 , 0 6 3}$ & $\mathbf{0 , 9 5 6}$ & 0,976 \\
$\begin{array}{l}\text { Rumah } \\
\text { Pengolahan Air }\end{array}$ & $\mathbf{0 , 8 7 1}$ & $\mathbf{0 , 2 5 6}$ & 0,415 & 0,632 & 0,807 \\
\hline \multicolumn{1}{c}{ Faktor } & $\mathbf{0 , 0 9 4}$ & $\mathbf{0 , 0 0 6}$ & 0,514 & 0,317 & 0,554 \\
\hline $\begin{array}{l}\text { Pendidikan } \\
\text { Kepadatan }\end{array}$ & $\mathbf{0 , 0 2 7}$ & $\mathbf{0 , 5 2 8}$ & 0,122 & 0,611 & 0,827 \\
$\begin{array}{l}\text { Penduduk } \\
\text { Jenis Rumah }\end{array}$ & $\mathbf{0 , 1 3 0}$ & $\mathbf{0 , 3 4 5}$ & 0,241 & 0,785 & 0,667 \\
Kepemilikan & 0,258 & 0,405 & 0,129 & 0,986 & $\mathbf{0 , 0 9 0}$ \\
$\begin{array}{l}\text { Rumah } \\
\text { Pengolahan Air }\end{array}$ & $\mathbf{0 , 0 4 0}$ & 0,514 & $\mathbf{0 , 0 2 4}$ & $\mathbf{0 , 0 0 0}$ & 0,762 \\
\hline
\end{tabular}

\subsection{Analisa faktor yang berpengaruh dalam pengelolaan tinja}

Infrastruktur pengolahan air tinja rumah tangga yang ada di Provinsi Maluku kondisinya tidak memadai, air limbah dari pengelolaan tinja yang dihasilkan disalurkan begitu saja. Kondisi ini menyebabkan pencemaran lingkungan yang berdampak pada kesehatan masyarakat. Jenis rumah dan kepemilikan rumah mempengaruhi kepemilikan tangki septik dan pembuangan tidak layak (Tabel 2). Salah satu upaya yang dapat dilakukan untuk pengelolaan tinja domestik untuk pulau kecil adalah membangun sistem penyaluran air buangan dan mengolahnya secara terpusat [31].

Tabel 2. Hasil perhitungan nilai signifikan setiap faktor terhadap pengelolaan tinja di Provinsi Maluku.

\begin{tabular}{lccc}
\hline \multirow{2}{*}{ Faktor } & $\begin{array}{c}\text { Tangki } \\
\text { Septik }\end{array}$ & SPAL & $\begin{array}{c}\text { Pembuangan } \\
\text { tidak layak }\end{array}$ \\
\cline { 2 - 4 } & Sig. & Sig. & Sig. \\
\hline Pendidikan & $\mathbf{0 , 7 4 5}$ & $\mathbf{0 , 7 2 8}$ & 0,726 \\
Kepadatan Penduduk & $\mathbf{0 , 9 2 2}$ & 0,544 & 0,956 \\
Jenis rumah & $\mathbf{0 , 0 7 7}$ & 0,506 & $\mathbf{0 , 0 5 2}$ \\
Kepemilikan rumah & $\mathbf{0 , 0 1 6}$ & $\mathbf{0 , 2 0 5}$ & $\mathbf{0 , 0 1 4}$ \\
Pengolahan air & $\mathbf{0 , 6 6 9}$ & $\mathbf{0 , 0 8 8}$ & $\mathbf{0 , 7 7 3}$ \\
\hline
\end{tabular}

Rumah tidak permanen seperti rumah apung cenderung tidak memiliki fasilitas pengolahan air buangan seperti tanki septik. Beberapa penelitian menyebutkan Se ptictank Terapung Received : February 19, 2020; Accepted: July 14, 2020; Available online: January 30, 2021 Copy right $\odot$ 2021, REGION: Jurnal Pembangunan Wilay ah dan Perencanaan Partisipatif 
dapat digunakan untuk menanggulangi masalah ini [32]. Pada sistem penyaluran air buangan faktor yang paling mempengaruhi adalah kondisi pengolahan air. Kondisi ketersediaan air yang kurang membutuhkan sistem penyaluran air limbah setempat lebih tepat digunakan dibandingkan sistem penyaluran limbah terpusat [33]. Pengolahan air buangan domestik sangat penting dilakukan untuk mengurangi dampak lingkungan yang mungkin ditimbulkan [34].

\section{Kesimpulan}

Akses air minum dipengaruhi oleh faktor pendidikan, kepadatan penduduk, jenis rumah, kepemilikan rumah, dan pengolahan air tergantung oleh sumber daya air yang digunakan. Pada sumber air minum kemasan dan air isi ulang faktor yang paling signifikan mempengaruhi adalah pendidikan, kepadatan penduduk, dan pengolahan air. Pengelolaan tinja dengan penggunaan tangki septik dan pembuangan tidak layak dipengaruhi oleh kepemilikan rumah dan jenis rumah. Sedangkan untuk pengolahan air dengan sistem penyal uran air limbah dipengaruhi oleh faktor pengolahan air yang telah dilakukan.

\section{Referensi}

[1] BPS 2018 Provinsi Maluku dalam Angka 2018 Diakses dari https://maluku.bps.go.id/publication/2018/08/16/ff1f52bdbd1b5938d5ef6206/pro vinsi-maluku-dalam-angka-2018.html

[2] Kementerian Pekerjaan Umum dan Perumahan Rakyat Direktorat Jenderal Ciptakarya 2016 Kebijakan, Strategi dan Program Keterpaduan Penanganan Kumuh Perkotaan Diakses dari https://docplayer.info/37307944-Kebijakan-strategi-dan-programketerpaduan-penanganan-kumuh-perkotaan.html

[3] Uar E D 2016 Strategi dan Tantangan Penanganan Kawasan Kumuh di Kota Ambon FIKRATUNA: Jurnal Penelitian Sosial Keagamaan 82 pp 127-44 Diakses dari https://iainambon.ac.id/ojs/ojs-2/index.php/FT/article/viewFile/362/294

[4] Peraturan Menteri Kesehatan Nomor 492 Tahun 2010 tentang Persyaratan Kualitas Air Minum Diakses dari http://www.ampl.or.id/digilib/read/24-peraturan-menterikesehatan-republik-indonesia-no-492-menkes-per-iv-2010/50471

[5] Hasbiah A W dan Kurniasih D 2019 Analysis of water supply and demand management in Bandung City Indonesia IOP Conference Series: Earth and Environmental Science 245 pp 1-6 DOI: 10.1088/1755-1315/245/1/012030

[6] Nastiti S I W, Kusnoputranto H, Boer R dan Utomo S W 2018 A Climate Risk Assessment of Clean Water Supply in An Urban Area: A Case Study of South Tangerang City, Indonesia IOP Conference Series: Earth and Environmental Science 129 pp 1-9 DOI: 10.1088/1755-1315/129/1/012027

[7] Apritama M R, Suryawan I W K, Afifah A S dan Septiariva I Y 2020 Phytoremediation of effluent textile WWTP for NH3-N and $\mathrm{Cu}$ reduction using pistia stratiotes Plant $\begin{array}{llllll}\text { Archives } & 20 & 1 & \mathrm{pp} & 2384-8 & \text { Diakses }\end{array}$ http://www.plantarchives.org/SPECIAL\%20ISSUE\%2020-1/2384-2388\%20(121).pdf

[8] Suryawan I W K, Helmy Q dan Notodarmojo S 2020 Laboratory scale ozone-based posttreatment from textile wastewater treatment plant effluent for water reuse Journal of Physics: Conference Series 1456 pp 1-7 DOI: 10.1088/1742-6596/1456/1/012002 
[9] Imroatus S, Mulyadi dan Maryam L 2015 Gambaran Sarana Sanitasi Masyarakat Kawasan Pesisir Pantai Dusun Talaga Desa Kairatu Kecamatan Kairatu Kabupaten Seram Bagian Barat Tahun 2014 HIGIENE: Jurnal Kesehatan Lingkungan 12 pp 75 83 Diakses dari http://journal.uinalauddin.ac.id/index.php/higiene/article/view/1237

[10] Hidayat A 2012 Analisis Sistem Sanitasi Lingkungan Berdasarkan Kebutuhan Penduduk Kota Masohi Kabupaten Maluku Tengah Jurnal Plano Madani 11 pp 86-96 Diakses dari alauddin.ac.id/index.php/planomadani/article/download/759/731

[11] BPS 2017 Statistik Kesejahteraan Rakyat Provinsi Maluku Tahun 2017 Diakses dari https://maluku.bps.go.id/publication/2017/12/29/daa87d4a3000acb99d2cced6/sta tistik-kesejahteraan-rakyat-provinsi-maluku-2017--hasil-susenas-2017-.html

[12] Dinas Kesehatan Provinsi Maluku 2017 Profil Dinas Kesehatan Provinsi Maluku 2017

[13] Sawhneya U 2013 Slum population in India: Extent and policy response International Journal of Research in Business and Social Science 21 pp 47-56 Diakses dari http://www.shram.org/uploadFiles/20140528064437.pdf

[14] Gupta I dan Guin P 2015 Health Status and Access to Health Services in Indian Slums Health 72 pp 245-55 DOI: 10.4236/health.2015.72029

[15] Jaiswal V 2016 Water and Sanitation Situation in Urban Slums of India: Evidence from NSSO International Journal of Health Sciences and Research (IJHSR) 65 pp 248-52 Diakses dari https://www.ijhsr.org/IJHSR_Vol.6_Issue.5_May2016/37.pdf

[16] Afandi W N 2010 Identifikasi Karakteristik Rumah Tangga Miskin di Kabupaten Padang Pariaman (Studi Kasus Nagari Malai V Suku) Jurnal Kemiskinan Diakses dari http://repository.unand.ac.id/20378/

[17] Elledge M F dan McClatchey M 2013 India, Urban Sanitation, and the Toilet Challenge RTI International Research Brief, USA pp 1-4 Diakses dari https://www.rti.org/rtipress-publication/urban-sanitation-toilet-challenge/fulltext.pdf

[18] Susilo G E, Purwadi O T dan Nurayni 2014 Studi Kebutuhan Air Domestik Untuk Daerah Pantai (Studi Kasus: Kota Bandar Lampung) Jurnal Rekayasa 183 pp 145-54 Diakses dari http://ftsipil.unila.ac.id/ejournals/index.php/jrekayasa/article/viewFile/191/269

[19] Kementerian Pekerjaan Umum Dan Perumahan Rakyat 2017 Buku Kinerja PDAM 2017 (Jakarta: Kementerian Pekerjaan Umum Dan Perumahan Rakyat badan Peningkatan Penyelenggaraan Sistem Penyediaan Air Minum) Diakses dari http://sim.ciptakarya.pu.go.id/bppspam/assets/assets/upload/BUKU_Lap_Kinerja_ PDAM_2017_FA.pdf

[20] Prasetyawati dan Malawat R 2018 Keberadaan Bakteri Esherichia Coli Pada Sumber Air Minum Di Desa Mamala Maluku Tengah Journal of Nursing and Public Health 62 pp 80-4 Diakses dari https://jurnal.unived.ac.id/index.php/jnph/article/view/640

[21] Setiawan T 2011 Hidrogeologi Dan Potensi Air Tanah Untuk Pertanian Di Dataran Waeapu, Pulau Buru, Maluku Buletin Geologi Tata Lingkungan (Bulletin of Environmental Geology $21 \quad 1 \quad$ pp $13-22$ Diakses dari https://docplayer.info/34192449-Hidrogeologi-dan-potensi-air-tanah-untukpertanian-di-dataran-waeapu-pulau-buru-maluku.html 
[22] Manuputty J, Gaspersz E Y dan Talakua S M 2014 Evaluasi Kemampuan Lahan dan Arahan Pemanfaatan Lahan di Daerah Aliran Sungai Wai Tina Kabupaten Buru Selatan Provinsi Maluku Agrologia Jurnal Ilmu Budidaya Tanaman 31 pp 62-74 DOI: 10.30598/a.v3i1.261

[23] Firdhausi N F, Rijal M dan Husen H Y 2018 Kajian Ekologis Sungai Arbes Ambon Maluku Jurnal Biology Science \& Education 71 pp 13-22 DOI: 10.33477/bs.v7i1.388

[24] Afifah A S, Suryawan I W K, Apritama M R, Prajati G dan Adicita, Y. (2019, October). Kinetics of organic and nutrient degradation with microalgae biomass cultured in photobioreactors In 2019 2nd International Conference on Applied Engineering (ICAE) pp 1-4 Diakses dari https://ieeexplore.ieee.org/abstract/document/9221749

[25] Ririmasse M 2012 Laut Untuk Semua: Materialisasi Budaya Bahari Di Kepulauan Maluku Tenggara Jurnal Penelitian dan Pengembangan Arkeologi 301 pp 56-69 DOI:10.24832/amt.v30i1.399

[26] Fathiyah F dan Wahab Z 2016 Analisis Faktor-Faktor yang Mempengaruhi Sikap Skeptis Konsumen Pada Iklan Hijau Journal of Magement and Business Review 131 pp 1-40 Diakses dari https://jmbr.ppm-school.ac.id/index.php/jmbr/article/download/32/20

[27] Widayat W 2005 Teknologi Pengolahan Air Siap Minum Untuk Daerah Jurnal Air Indonesia 12 pp 132-142 DOI: 10.29122/jai.v1i2.2341

[28] Yudo S dan Raharjo, P 2005 Evaluasi teknologi air minum isi ulang di DKI Jakarta Jurnal Air Indonesia 13 pp 251-263 DOI: 10.29122/jai.v1i3.2353

[29] Sugeng A, Purnomo S E C dan Hudiono 2012 Perilaku Hidup Bersih dan Sehat pada Tatanan Rumah Tangga (Phbs Rt) di Desa Sidorejo Kecamatan Brangsong Kabupaten Kendal Link $\quad 8 \quad 2$ Diakses dari http://ejournal.poltekkessmg.ac.id/ojs/index.php/link/article/download/289/228

[30] Mende J C C, Kumurur V A dan Moniaga I L 2015 Kajian Sistem Pengelolaan Air Limbah Pada Permukiman Di Kawasan Sekitar Danau Tondano (Studi Kasus: Kecamatan Remboken Kabupaten Minahasa) Sabua: Jurnal Lingkungan Binaan dan Arsitektur 7 $1 \quad$ pp $395-406 \quad$ Diakses dari https://ejournal.unsrat.ac.id/index.php/SABUA/article/view/8274

[31] Adicita Y, Suryawan I W K dan Apritama M R 2020 Design of Centralized Wastewater Sewerage System in Small Lengkang Island, Batam City, Indonesia Journal of Community Based Environmental Engineering and Management 41 pp 15-24 DOI: 10.23969/jcbeem.v4i1.2250

[32] Santosa D E, Angela B, Fandhi V, Prabowo I, Dwinanda O, Mulyani T H dan Listiati E E 2017 Rumah Amfibi sebagai Solusi Ekologis untuk Mengatasi Rob Prosiding Seminar Nasional Arsitektur Populis pp A27-A39 Diakses dari http://repository.unika.ac.id/15675/2/Rumah\%20Amfibi.pdf

[33] Rachman D N 2018 Penggunaan Tripikon-S Sebagai Alternatif Penggunaan Septic Tank Di Daerah Tepian Sungai Dan Rawa Jurnal Tekno Global 51 pp 40-49 DOI: 10.36982/jtg.v5i1.384

[34] Suryawan I W K dan Sofiyah E S 2020 Cultivation of Chlorella Sp. and Algae Mix for NH3-N and PO4-P Domestic Wastewater Removal Civil and Environmental Science Journal 31 pp 31-36 DOI: 10.21776/ub.civense.2020.00301.4 